DOI: $10.17516 / 1997-1370-0622$

УДК $782.1+82-293.1$

\title{
Peculiarities of Adaptation of the Novel by F.M. Dostoyevsky "The Idiot" in the Opera by M. Weinberg of the Same Name
}

\author{
Svetlana G. Voitkevich* \\ Dmitri Hvorostovsky Siberian State Academy of Arts \\ Krasnoyarsk, Russian Federation
}

Received 02.05.2020, received in revised form 05.06.2020, accepted 10.06.2020

\begin{abstract}
The article is devoted to the issues of correlation between the literary source and the musical drama. The opera "The Idiot", finished by the Russian composer Mieczystaw Weinberg in 1986 and performed on the leading Russian stages in the creative season of 2016-2017, has become the object of scientific interest. The libretto written by A.V. Medvedev is based on the novel by F.M. Dostoevsky of the same name. Musical studies of Dostoevsky's works started emerging during the life of the writer. It was expressed in the use of musical terminology in the criticism and scientific studies concerning literary works by F.M. Dostoevsky. In 1916, S.S. Prokofiev created the opera "The Gambler", which became the first opera adaptation of the writer's prose, congenial with the literary source. Since then, the creative heritage of the author of "Demons" has repeatedly attracted composers' attention. Musical adaptations of Dostoevsky's literary works today comprise more than seventy compositions in various genres. Operas are of particular interest, since dramatic and musical texts are equally important in conveying the implications of the writer's novels. The specific features of the interaction of prose and musical drama in this article are revealed using the intertextual analysis methods, which highlight the relevance of the topic addressed. The libretto is studied as an important component of the opera in the light of the trends of the modern science of music. The techniques of the dramatist's work with the literary source are considered. The libretto texts that are not introduced in the novel and their sources are revealed; the logics of the reference of the "The Idiot" opera creators to Dostoevsky's meta-text and the legacy of other authors in the context of artistic conception are explained. The article determines the functions of the characters of the first and second action plan, gives their brief description and indicates their role in the dramaturgy of the opera.
\end{abstract}

Keywords: F.M. Dostoevsky, M.S. Weinberg, A.V. Medvedev, Russian modern opera, librettology.

Research area: musical art.

(C) Siberian Federal University. All rights reserved

* Corresponding author E-mail address: art-vice-rector@yandex.ru ORCID: 0000-0002-4437-0439 
Citation: Voitkevich, S.G. (2020). Peculiarities of adaptation of the novel by F.M. Dostoyevsky "The Idiot" in the opera by M. Weinberg of the same name. J. Sib. Fed. Univ. Humanit. Soc. Sci., 13(6), 989-996. DOI: 10.17516/1997-1370-0622.

\section{Introduction}

The history of musical studies of Dostoevsky dates back to the 19th century. Even during the life of the writer the characteristics of the novel "The Brothers Karamazov" as "a highly integral, semi-tragic, semi-clear opera in which menacing and sad sounds alternate with obscure and touching ones" can be found in critical articles by K.N. Leont'ev (Dostoevsky, 1976: 622). The assessment of Dostoevsky's literary works by a Russian philosopher Vyacheslav Ivanov is also indicative: "Similar to the composer who wrote symphonies, he used his mechanism for the architectonics of tragedy and applied a method similar to the thematic development of the main phrases-motifs in music to the novel, the development, which turns and metamorphoses are used by a composer to bring us to the aesthetic and psychological experience of the whole composition as a kind of unity" (Dostoevsky and the Novel-Tragedy, 1990: 171).

In search of the most accurate definition of the structure of the author's novels M.M. Bakhtin in his work "Problems of Dostoevsky's Poetics" addressed musical terminology, which led to the appearance and description of the idea of the "polyphonic novel". A similar analogy arose due to the writer's comprehension of a character as a subject, but not an object of the author's or another character's consciousness. A "polyphony" of consciousnesses and ideas about the world arises as a result. Like the lines of polyphony, their interaction forms a complex musical fabric. The combination and contrast with other "characters-themes" give an opportunity to indicate the uniqueness and originality of each character more intensely.

A few decades later in the fundamental study "Dostoevsky and Art of Music and Theatre" A.A. Gosenpud comprehensively describes the influence of music on the formation of the personality and fictional world of the literary works by Dostoevsky. He notes that "in Dostoevsky's literary works images develop according to musical laws - they constantly come back as memories, or as a real experience and each time they sound in a new way, as if in a different tonality (Gozenpud, 1971: 135). The scientist clarifies M.M. Bakhtin's concept and offers to use the term "counterpoint" in relation to Dostoevsky's novels, since two consciousnesses and two voices in F.M. Dostoevsky's literary works are a minimum that is necessary to build the concept and to which the writer limited himself only at an early stage of his creative work. Late novels by Dostoevsky are polyphonic works, where the combination of several models of existence simultaneously resembles the techniques of double and even triple counterpoint.

Musical terminology also arises in the process of analysing the structure of the literary works by the Russian classical writer. In this way, A.A. Gosenpud writes about the penetration of the principles of repetition and reprise into the composition of the novels "White Nights" and "Crime and Punishment". G.M. Fridlender finds that while forming a "complex musical and symphonic unity" the composition and grouping of the characters of "The Adolescent", "Crime and Punishment", "The Idiot", "The Gambler", and "The Brothers Karamazov" correspond to the principles of a musical composition organisation. There is a clear resemblance to the themes of a sonata allegro, a slow part and a fervently humorous Scherzo and, at the end "at the same time a deeply tragic and exaltedly optimistic ending, in which the mood of deep sorrow and despair mixes with a sense of "seraphic" height of spirit in the reader's perception" sounds (Fridlender, 1995: 301).

It is especially necessary to emphasise that research of scientists who study Dostoevsky's works is literally full of musical terminology. Assimilation of human voices to registers in which variations of the main theme are carried out; comparisons of the novel collisions with musical contrasts and dissonances; analogies 
of conflicting scenes of novels with opera ensembles and chain finale-buffa, as well as many other things can be found in them.

The emerging analogies with music are not accidental. They became a reflection of the complex fictional world of F.M. Dostoevsky's literary works and were one of the reasons for composers' interest in the literary work of the classical Russian author. In 1900, V.I. Rebikov wrote the opera "The Christmas Tree". The basis of the libretto was the fairy tale "The Little Match Girl" and the story "The Beggar Boy at Christ's Christmas Tree" by H.C. Andersen published in the January issue of "A Writer's Diary" in 1976. However, the opera by S.S. Prokofiev "The Gambler", created in 1916 became the starting point of musical studies of Dostoevsky.

Since that time, composers have written almost a hundred compositions inspired by Dostoevsky's prose. Their genre diversity is rather big: opera (in all its varieties), musical drama, overture, ballet, suite, vocal and instrumental symphony, symphonic poem, vocal cycle, musical and oratorio. With all the variety of genre interpretations, musical and drama opuses undoubtedly occupy the "leading positions". They give an opportunity to consider issues concerning the creative legacy of the writer in the light of the interdisciplinary scientific discourse using intertextual analysis methods, which have been actively developing over the past decades.

\section{Theoretical framework}

Analytical studying of the opera composition starts with the consideration of the libretto, which forms the dramatic basis of the composition. In this regard, it is important to understand the methods of "working" with Dostoevsky's prose, the ways of "interpreting" and adapting a prosaic text for a vocal composition, which give literary characters an opportunity to "sound" from the musical scene in the future.

Publications about the need to study the libretto as an independent text, largely influencing a composer's work, first started appearing on the pages of professional periodical publications from the middle of the $20^{\text {th }}$ century. How- ever, librettology itself as a separate branch of musicology, dealing with the history and theory of libretto, has been developing only since the late $20^{\text {th }}$ century. In modern Russian science, the largest number of studies devoted to this topic belongs to G. Ganzburg (Ganzburg, 2004). The basic materials on librettology and librettistics are available on the website " $\mathrm{Li}$ bretto in A Dream and in Reality", created by a playwright, writer, and librettist Yu.G. Dimitrin in 2000 . He is also the author of the studies devoted to the issues of the history and methodology of librettology as a separate and independent branch of musicology (Dimitrin, 1997; Dimitrin, 2009; Dimitrin, 2011). The issues of a literary text interpretation into the opera and the interaction between literature and music can be found in the studies of literary scholars, culture specialists and philologists (About the Special Features of Interpretation of the Literary Source..., 2015; The Opera Librettistics and Russian Literature, 2007; The Opera Librettistics and Russian Literature, 2019), denoting the relevance of this scientific area and its interdisciplinary nature.

\section{Statement of the problem}

The opera "The Idiot" was the seventh and final composition of the musical and stage genre in the creative heritage of Mieczystaw Weinberg (1919-1996). The fates of his compositions in this genre were different. "The Madonna and The Soldier", "Congratulations!", and "The Love of d'Artagnan" were staged in the capital's theatres; the first performance of the opera "The Portrait" was held in Brno; the opera "Zosya" is still in the archives of the composer's family, and unfortunate "The Passenger" had been waiting for its first performance for 38 long years.

The opera "The Idiot" stands out among these works. On the one hand, it was staged during the composer's life in 1991 at the Chamber Theatre. However, according to the magazine review, a "new version", in which director B.A. Pokrovsky made "some cuts (about 50 minutes of music)" was created for this purpose (Variations on The Theme of "The Idiot", 1992: 54). The degree of these reductions can be seen at least in the fact that the author of the arti- 
cle calls Weinberg's composition "the chamber opera". Meanwhile, its original composition: 4 acts, 10 scenes, 14 characters, three of which are mimic roles, as well as the participation of the male choir and full orchestra (in the original version) at least give reason to doubt the validity of the abovementioned genre definition.

It should be noted that the scenes from the opera were twice (in 1987 and 2011) staged by graduate students at The Russian University of Theatre Arts. However, in this case it is impossible to talk about a full-fledged production. The opera was first staged in the original author's edition in 2013 on the stage of the Mannheim National Theatre. In the 2016-2017 season, the Bolshoi Theatre in Moscow and the Mariinsky Theatre in St. Petersburg presented their versions of Weinberg's opera. The analysis of the libretto in comparison with the literary source demonstrates that the playwright A.V. Medvedev in the text of the opera used texts that are not introduced in the novel. It seems important to identify the ways and methods of the librettist's work to determine the main ideas of the opera drama and to identify the degree of the text influence on the musical dramatic art.

\section{Discussion}

Mieczysław Weinberg and librettist Alexander Medvedev offered their own interpretation of one of the most famous literary works by Dostoevsky. The fact that this theme is most in demand among the musical theatre figures is of interest. Nowadays, there are 7 ballet and 6 opera productions, representing stage versions of the novel "The Idiot". It is also demonstrative that only two composers - V.M. Bogdanov-Berezovsky (opera "Nastasya Filippovna") and V.A. Kobekin (opera "N.F.B.") - changed the name compared to the literary source. In other cases, there are such titles as "The Idiot" or "Prince Myshkin", which is understandable, since the main character of F.M. Dostoevsky's novel is Prince Lev Nikolayevich Myshkin, which image embodied the writer's idea of a "a rather wonderful person". Myshkin's special "existence" in the novel is mainly determined by the conception of the novel, which N.A. Berdyaev calls "centrifugal" (Berdyaev, 1991). Its meaning is that the prince, like Al- yosha and the elder Zosima in "The Brothers Karamazov" "unravels other people" and "is busy with everyone" (About Dostoevsky, 1990).

The word "idiot" has many interpretations and explanations which, according to Dostoevsky's letters, were known to him. It is necessary to note only one of them, which refers us to the medieval literary tradition, where an idiot was a person who was not well-educated, but "endowed with ideal traits and deep spirituality." An idiot was a typical character who comprehended "the ways of familiarising with the higher secrets of existence" (Dostoevsky, 1976: 622). As if highlighting this aspect of the image of Myshkin, Weinberg and Medvedev provided this character with detailed monologues, which he typically sings being on stage alone. Moreover, in most cases the text of these episodes is a kind of a "free adaptation" of Dostoevsky's texts transferred from the narrative form into the "first-person" speech.

The work done by Alexander Viktorovich Medvedev with the literary source deserves special attention. From the point of view of the storyline, the opera is a complete copy of F.M. Dostoevsky's novel. The logics of events can be seen in the names of the scenes given by the librettist: "Meeting on the Train," "At the Epanchins", "At the Ivolgins", "Day of the Angel", "At Rogozhin's", "The Faithful Knight", "Two Meetings", "Lebedev's Confession", "Rivals" and "Reconciliation". It is obvious that the libretto's author follows the sequence of four parts of Dostoevsky's novel. At the same time, within the scenes, he freely combines the phrases that can be found in one or different chapters of the novel to accentuate a specific idea of a character. This happens, for example, in a small monologue by Ganya Ivolgin, which can be likened to a kind of the character's Credo about the omnipotent power of money (scene 2) or in the arioso of general Yepanchin's wife from scene 6, lamenting about her daughters' fate.

The cases when the texts that cannot be found in the novel appear in the opera are even more interesting. Scene 3 starts with a solo arioso of Myshkin. His main idea is revealed by the famous phrase borrowed by the libret- 
tist from the letter of eighteen-year-old Dostoevsky to his brother Mikhail: "Man is a mystery. It needs to be unravelled, and if you spend your whole life unravelling it, don't say that you've wasted time; I'm studying this mystery because I want to be a human being" (Dostoevsky, 1985: 63). Compare with the text of the libretto: "Truth! It is so clear and simple: people can be beautiful and happy in this world! I do not believe, I will never believe that evil is ordinary for human life! Man is a mystery. It needs to be unravelled. But is life enough for this?" (Weinberg, 1992: 122-123).

Another example is found at the beginning of scene 4 . The action takes place in the house of Nastasya Filippovna who is celebrating her birthday. To create a festive and relaxed atmosphere, Lebedev entertains guests singing romances, accompanying himself by playing the piano. There is nothing similar to this scene in the literary source. However, the domestic genre was extremely popular in the mid-19th century and was as a kind of "a sign of the times". It is known that romances sounded in F.M. Dostoevsky's house, and there were often references to the vocal works of his contemporaries on the pages of his literary works. Finally, Ferdyshchenko's phrase, "And I'll have the prince start by singing a fashionable romance" (Dostoevsky, 1973: 117) which was said when Myshkin appeared, could become the reason for the authors of the opera "The Idiot". Since Ferdyshchenko is not in the list of the opera characters, his phrases are given to Lebedev. The librettist uses fragments of the poems "A Spring Night" by N. Yazykov and "The Last Breath" by Y. Polonsky as the texts for the role of Lukyan Timofeevich. The appearance of the poetry by Y.P. Polonsky in the libretto of the opera based on the novel by Dostoevsky can be explained by the friendship that connected the writer and the poet for many years. The appeal to the poem by N. Yazykov is remarkably interesting and significant. An amazing person of naturals talents and a descendant of a wealthy family, Nikolai Mikhailovich was a great success during his studies in the student community, where songs were often composed and sung based on his poems. According to the researcher, Yazykov himself "agreed to recite his verses only at the parties when he was completely drunk" (Rezepov).

Another example of the text that is not represented in the novel is the scene of Rogozhin, in which the verbal and musical version of the Russian folk song "Oh, My Good Fortune (Ax, талан ли мой, талан)" sounds. The stanzas performed by Rogozhin are a kind of frame for Lebedev's story about the failed Myshkin and Nastasya Filippovna's wedding and about her escape from the wedding to Rogozhin. The analysis of the available texts demonstrated that the song "Oh, My Good Fortune (Ax, талан ли мой, талан)" can be found in the oral tradition in different variants. Their diversity can be reduced to two types: a wedding song and a ballad prison song with the stable archetype of "a beauty and a robber". In the context of the scene described above, each type finds its own semantic correlate. This, apparently, became the reason why the authors of the opera "The Idiot" used the lyrics and the music of this song. At the same time, the librettist and the composer complemented the folklore source, increasing the tragic focus of the source text.

Some scenes contain the events of different chapters, which gives an opportunity to activate the course of action, while preserving the intensity of its development and the "agglomeration" of events that are so characteristic of Dostoevsky's novels. Perhaps this property of the Russian classical writer's style, coupled with the requirements of the opera genre, necessitated the use of the cinematography technique of "combining plans". The skilful application of the editing principle is understandable. Weinberg composed music for more than 60 films, the most famous of which are: The Cranes are Flying, Afonya, The Tiger Tamer, Honeymoon, The Hyperboloid of Engineer Garin, and Teheran-43.

In the piano score, the authors indicate that "the opera's action takes place on three platforms located on the main stage. The actions on each of them take place separately, with instantaneous transitions" (Weinberg, 1992: 3). Due to this technique, the authors solve several problems. Firstly, it allows to concentrate the action and emphasise some situations. For instance, in the first scene, Rogozhin and Mysh- 
kin meet on the train. Parfen tells about his feelings for Nastasya Filippovna. In the middle of this episode "the female character's room" where she meets Ganya Ivolgin and gives the portrait to the potential fiancé "is backlighted". In Dostoevsky's novel this scene can be found later in Ivolgin's retelling. In addition, let us recall that in the novel Nastasya Filippovna personally appears one of the last, although she is mentioned almost from the beginning of the novel. Thus, the authors of the opera immediately introduce Nastasya Filippovna as the main female character of the drama and show a scene with a portrait that will create a conflict in the scene "At the Epanchins"" when Myshkin meets a noble family.

Secondly, the "scene change" technique makes it possible to "collide" various ideas personified in the characters. In the second scene, the action takes place in the Epanchins' house. Myshkin meets with the general's wife and her daughters in the living room, and on another platform, representing the study, Ganya calculates income. After the prince's short arioso, where he enthusiastically shares his dreams of a "new life", Ivolgin's mercantile and business-like abrupt phrases sound. He calculates possible dividends from the sum of money he might get for marrying Nastasya Filippovna. The next Yepanchina's remark to Myshkin, as if clarifies the meaning of this "collision": "So you are a dreamer! This is good, my dear friend. Because heart is the main thing, and all the rest is nonsense!" (Weinberg, 1992: 80-81).

The technique of instant transitions simplifies the perception of what is happening and helps to comprehend the author's message. Due to this technique, Dostoevsky's complex "contrapuntal" novel seems to develop horizontally, while retaining the integration of various ideas vertically within the same scene.

As for the presentation of individual characters of the opera, it is necessary to note the unusual role of Lebedev, who, at first glance, can be attributed to the "secondary" characters. However, his function is extremely important and extensive. In addition to the familiar role of a participant in events, in the opera he acts as a reasoner and narrator. This explains rather frequent appearance of Lebedev in the foreground with a parte phrases. At the beginning of scene 2 , he turns to the audience and explains the meaning of the dialogue between Totsky and Yepanchin, who "were bargaining" Nastasya Filippovna to marry her off to Ganya Ivolgin. At the end of the same scene, Lebedev, according to the acting, "jumps out to the front of the stage" with the phrase "No, gentlemen! This strange day has not finished yet! We are in for extraordinary events!" (Weinberg, 1992: 118-119). Scene 6 of the opera is marked by Aglaya's beautiful ballade "The Faithful Knight". Performing it, the character replaces the letters of the motto inscribed on the knight's shield: instead of "A.M.D." (Ave Maria Dei) she says "N.F.B.". Compliant Lebedev immediately explains the essence of the replacement: "Nastasya Filippovna Barashkova" (Weinberg, 1992:290). It is also necessary to mention the final scene, where Lebedev talks about the failed wedding of Myshkin and Nastasya Filippovna. His speech is interrupted by the vocal phrases of characters, sounding from behind the curtains. This diversified interpretation of the image of Lebedev is predetermined by Dostoevsky's novel, where from the very first pages he is introduced as "Mr. Know-ItAll" and, on the one hand, appears under the guise of a jester, but at the same time he positions himself as an interpreter of the Apocalypse and is not devoid of vain claims for the role of the "World Leader". It is Lebedev, who spinning intrigues and playing on the feelings of the main characters, gradually models some situations to rise in his own esteem, while humiliating himself before others.

Another character of the opera, who is not represented in the novel, deserves mentioning. This is a Knife Grinder. He appears twice: in scenes 5 and 10. There is a knife in both scenes, which has the leitmotif status in the novel. Consequently, a terrible object that terminates Nastasya Filippovna's life is as if personified by the image of the Knife Grinder.

\section{Conclusion}

The brief review of Weinberg's opera "The Idiot" suggests that following Dostoevsky its authors presented their own vision of the novel. This composition is extremely interesting and 
rich in findings, and individual in its musical language, revealing the main features of Dostoevsky poetics. This is achieved by introducing texts that cannot be found in the novel, giving the phrases of some characters to others, using the principle of editing at the textual and dramatic levels and clashing of ideas personified in the opera characters.

F.M. Dostoevsky's prose is of interest to musicians. Currently, Alexander Smelkov is completing work on the score of the opera "The Idiot", conceived as the second part of the tetralogy by F.M. Dostoevsky. In March 2019, the premiere of the rock opera "The Karamazovs" by Alexander Ragulin took place on the stage of the Central House of Art Workers. All this indicates of the enduring interest of the contemporary musical scene in the literary work of the great Russian writer.

\section{References}

Berdyaev, N.O. (1991). O russkoi filosofii [About Russian Philosophy]. Part 1. Ekaterinburg, Ural'skii universitet, $240 \mathrm{p}$.

Dimitrin, Yu.G. (1997). Nam ne dano predugadat' [We Cannot Predict] Saint-Petersburg, Severnyi olen', 110 p.

Dimitrin, Yu.G. (2011). Libretto: istoriia, tvorchestvo, tekhnologiia. Uchebnoe posobie v zhanre esse [Libretto: History, Creative, Technology. Essay Study Guide]. Saint-Petersburg, Kompozitor, 171 p.

Dimitrin, Yu.G. (2009). Pokhozhdeniia librettista [The Librettist's Adventures]. Saint-Petersburg, Informatsionnye resursy, $168 \mathrm{p}$.

Dostoevsky, F.M. (1973). Polnoe sobranie sochinenii v 30 tomakh. Tom 8 [Complete Set of Works in 30 Vol. 8]. Leningrad, Nauka, 514 p.

Dostoevsky, F.M. (1974). Polnoe sobranie sochinenii v 30 tomakh. Tom 9 [Complete Set of Works in 30 Vol. 9]. Leningrad, Nauka, 387 p.

Dostoevsky, F.M. (1976). Polnoe sobranie sochinenii v 30 tomakh. Tom 15 [Complete Set of Works in 30 Vol. 15]. Leningrad, Nauka, 622 p.

Dostoevsky, F.M. (1985). Polnoe sobranie sochinenii v 30 tomakh. Tom $28 \mathrm{Kn}$. 1. [Complete Set of Works in $30 \mathrm{Vol}$. 8, Book 1]. Leningrad, Nauka, 554 p.

Fridlender, G.M. (1995). Pushkin. Dostoevskii. Serebrianyi vek [Pushkin. Dostoevsky. The Silver Age]. Saint-Petersburg, Nauka, 576 p.

Ganzburg, G.I. (2004). Librettologiia: status i perspektivy [Librettology: Status and Prospects]. In Muzichne mistectvo: Zbirka naukovih statej. Donetsk, 4, 27-34.

Gozenpud, A.A. (1981). Dostoevskii i muzikal'no-teatral'noe iskusstvo [Dostoevsky and Art of Music and Theatre]. Leningrad, $224 \mathrm{p}$.

Ivanov, V.V. (1990). Dostoevskii i roman-tragediia [Dostoevsky and The Novel-Tragedy]. In O Dostoevskom: Tvorchestvo Dostoevskogo v russkoi mysli [About Dostoevsky. Dostoevsky's Literary Work in Russian Thought]. Moscow, Kniga, 164-192.

Kovaleva, M.N. (2015). Ob osobennostiakh interpretatsii literaturnogo pervoistochnika v opere R. Shchedrina "Ocharovannyi strannik" [About the Special Features of Interpretation of the Literary Source of Rodion Shchedrin's Opera “The Enchanted Wanderer"]. In Problemy muzykal'noi nauki [Music Scholarship], 1, 126-130.

Pivovarova, I.L. Opernaia librettistika i russkaia literatura [The Opera Librettistics and Russian Literature]. In Vestnik MaGK, 2, 57-72

Polyakov, I.A. (2019). Roman A.S. Pushkina Evgenii Onegin v libretto odnoimennoi opery P.I. Tchaikovskogo: spetsifika transformacii [Some Peculiarities of Impersonation of The Main Characters from A. Pushkin's Novel in Verse "Eugene Onegin" in P. Tchaikovsky's Opera Libretto]. In Culture and Text, 2 (37), 157-167

Rezepov, E. (2011). K Yazykovu [To Yazykov]. Russkii mir.ru. [Russian World]. Available at: https:// teology.academic.ru/4615/secularity (accessed 17 July 2017).

Vlasov, A. (1992). Variatsii na temu "Idiota" [Variations on The Theme of "The Idiot"]. In Musical Academy, 4, 54-57. 
Weinberg, M.S. (1994). Idiot: Opera v 4 d.: Op. 144. Libretto A. Medvedeva (po odnoimennomu romanu F.M. Dostoevskogo) [The Idiot. Opera in 4 Acts. Op.144. Libretto by A. Medvedev (Based on The Novel of The Same Name by Dostoevsky)]. Moscow, Kompozitor, 407 p.

\title{
Особенности прочтения романа Ф.М.Достоевского «Идиот» в одноименной опере М. Вайнберга
}

\author{
С.Г. Войткевич \\ Сибирский государственныий институт искусств \\ имени Дмитрия Хворостовского \\ Российская Федерачия, Красноярск
}

\begin{abstract}
Аннотация. Статья посвящена вопросам взаимодействия литературного первоисточника и музыкальной драмы. Объектом научного интереса становится опера «Идиот», завершенная в 1986 году отечественным композитором Мечиславом Вайнбергом и поставленная на ведущих российских сценах в творческом сезоне 2016-2017 года. Либретто написано А.В. Медведевым по одноименному роману Ф.М. Достоевского. Музыкальная достоевистика начала зарождаться еще при жизни писателя. Она выражалась в использовании музыкальной терминологии в критике и научных исследованиях, касающихся литературных произведений Ф.М. Достоевского. В 1916 году С.С. Прокофьев создал оперу «Игрок», ставшую первым оперным прочтением прозы писателя, конгениальным литературному первоисточнику. С тех пор творческое наследие автора «Бесов» не раз привлекало внимание композиторов. Музыкальная достоевистика сегодня насчитывает более семидесяти сочинений в разных жанрах. Особый интерес представляют оперы, поскольку в них драматический и музыкальный тексты одинаково важны для передачи глубинных смыслов романов писателя. Специфика взаимодействия прозы и музыкальной драматургии в данной статье выявляется с использованием методов интертекстуального анализа, что сообщает актуальность обращению к данной теме. Либретто исследуется как важный компонент оперного сочинения в свете тенденций современной музыкальной науки. Рассматриваются приемы работы драматурга с литературным первоисточником. Выявляются внероманные тексты либретто, их источники; объясняется логика обращения создателей оперного «Идиота» к метатексту Достоевского и наследию других авторов в контексте художественного замысла. Определяются функции персонажей первого и второго плана действия, дается их краткая характеристика, обозначается роль в драматургии оперы.
\end{abstract}

Ключевые слова: Ф.М. Достоевский, М.С. Вайнберг, А.В. Медведев, современная отечественная опера, либреттология.

Научная специальность: 17.00.02 - музыкальное искусство. 